\title{
Intergenerational Differences as a Challenge of Leaders in the Process of Building Commitment of Employees in a Public Organization - An Empirical Research
}

Submitted 15/03/21, $1^{\text {st }}$ revision 08/04/21, $2^{\text {nd }}$ revision 29/04/21, accepted 25/05/21

\author{
Maria Jabłońska-Wołoszyn ${ }^{1}$, Dorota Kurek ${ }^{2}$
}

\begin{abstract}
:
Purpose: The article aims to show what challenges stem from employees' generational diversity and determine the level of engagement that leaders face in a public organization, using the example of the army.

Design/Methodology/Approach: To answer the research problem, an analysis of the source literature (both Polish and foreign) together with a diagnostic survey was carried out with the use of questionnaire techniques on a sample of 158 soldiers - students and attendees of the courses conducted at the War Studies University in Warsaw. The results of the research were subjected to statistical analysis, which allowed to answer the research problem.

Findings: The conducted research confirmed the existence of different thinking patterns of the representatives of generations $X, Y$, and $Z$, which constitutes a challenge for commanders in the army. The differences were noticed, especially about generation $Z$ in the scope of interpersonal relations, teamwork, and work organization.

Practical Implications: The results of the research are significant in the process of building the commitment of employees in public institutions. They reveal differences in the needs and expectations of a multigenerational team, which undoubtedly spur challenges for the leader to reconcile these needs and directly impact the level of commitment and, therefore, the ability to achieve the set goals.
\end{abstract}

Originality/Value: The research provides theoretical assumptions and practical answers to encourage further research globally.

Keywords: Intergenerational differences, leader, public organization.

JEL classification: J5, J1.

Paper Type: Research article.

\footnotetext{
${ }^{1}$ War Studies University, Management Institute, Management and Command Department, m.woloszyn@akademia.mil.pl;

${ }^{2}$ War Studies University, Management Institute, Management and Command Department, d.kurek@akademia.mil.pl;
} 


\section{Introduction}

The diversity of the workforce commonly referred to as generational diversity has become the subject of research, analysis, and conclusions to explain the complexity of the issue while also revealing its multifaceted nature. The functioning on the labor market of the representatives of mainly three generations of employees - the so-called employee generation, i.e., people with different attitudes, values, and needs, determines the necessity of multigenerational management and is connected with the need for a complete diagnosis of the target group of employees, in order to design personal activities in such a way, that the organization, in the opinion of the indicated group, would obtain the title of employer of choice (enjoy a perfect brand). The indicated activity becomes at the same time a challenge faced by contemporary leaders - people in charge, among others, functioning in public organizations, in which the generational differences of employees are particularly conspicuous.

According to statistical data, in 2019, there were 9578.6 thousand employees in Poland. In the public sector, 3045.1 thousand people found employment, $32 \%$ of the total number of employees. Within this group, 153.5 thousand military employees were recorded, including 107.7 thousand soldiers and 45.8 thousand civilian employees (CSO, 2020).

Considering the importance of the Polish army as the employer, as well as the fact that the contemporary labour market is not homogenous, during the conducted empirical research, the issue of generational differences that the leader in the army as a public organization must cope with was analysed, emphasizing the army as a workplace for soldiers coming from generations $\mathrm{X}, \mathrm{Y}$ and $\mathrm{Z}$.

\section{Generations in the Labour Market - Generational Differences}

Awareness of the generational diversity of employees, and therefore the diversity of the workforce in terms of emotions, needs, expectations, approach to work, and interpersonal relations, is an issue getting more and more traction among theoreticians, as well as practitioners in the field of human resource management (HRM). As stressed by Costanza et al. (2017), research on generational differences has been an active area across a variety of domains for over 50 years and has surged in the past 20 years or so. Ongoing discussions and the results of empirical studies show a division of researchers into two groups: confirming the significance of generational diversity on individual, professional and social performance, and those little perceiving correlation in this context (Costanza et al., 2017; Twenge et al., 2010; Trzesniewski and Donnellan, 2010).

The term generation itself means a group of people of similar age or a cohort of persons passing through time that come to share a typical habitus, his and culture, a function of which is to provide them with a collective memory that serves to integrate the cohort over a finite period (Eyerman and Turner, 1998). The criterion based on 
which a given work can be classified in a specific generational group is age or the year of birth. However, analysing the source literature, it is not easy to find uniformity of views on the time frame determining generational affiliation (Lyons, Schweitzer, and Eddy, 2015; Mazur-Wierzbicka, 2015; Ruth et al., 2013; Smola and Sutton, 2002). Although the timeframe remains a matter of debate, the following ranges can be assumed: generation X are employees born between 1965 and 1980, generation Y are employees born between 1981 and 1997, and generation $\mathrm{Z}$ are employees born after 1998.

According to Haynes (2011) "The changing demographic trends mean that for the first time, there is a possibility that four generations of people could be working alongside each other in today's workplace. The four different generations can be categorized as four distinct groupings". In addition, “...each generation may have their workplace expectations" (Haynes, 2011). The divergence of views of the representatives from different generations is particularly discernible about workplace preferences, specifics of expected working conditions, the role of work in people's lives, preferred modes of communication, work style, and factors motivating people to work. Accounting for the generational differences, it might be pointed out that generational differences in people's attitudes and values are the results of significant economic, political, and social events that they experience during their formative years of childhood (Bensona and Brown, 2011). It is also confirmed by Mannheim (1952), McMullin et al. (2007), Schuman and Scott (1989).

The diversity of views regarding the perception of work and the role of work in human life makes organizational management a challenge for contemporary leaders. The diversity of approaches to work may ultimately be a source of conflict between representatives of different generations, affecting interpersonal relations, teamwork, and the authority of superiors. Such a situation may occur, especially when the leader in an organization is, for example, a representative of generation $\mathrm{X}$, and a representative of Generation $\mathrm{Z}$ is a regular employee. This is because understanding the expectations and needs of different groups of employees (Goštautaite et al., 2019) makes it possible to shape the working conditions, systems intentionally, and processes in the organization, the effects of which can be seen both in terms of financial performance, interpersonal relations, and job satisfaction.

\section{A Leader in a Public Organisation}

In the public sector, due to the specificity of the organizational culture, differences can be found in how leadership is considered and recognized, assigned to a given position. Particularly in organizations such as the military and other uniformed services, a leader is appointed to a position, and the extent of his or her formal authority is defined by the leadership span (Ingraham and Getha-Taylor, 2004).

The complexity of approaches and the way leadership research is conducted results in a multiplicity of definitions and theories in the literary references, which stems 
from differing views on the sources of leadership, how leadership competencies are developed, or the extent of the relationship between leadership and particular dimensions of work (e.g., interpersonal relationships, teamwork, or work organization) (Clifton et al., 2020).

Avery (2009), shows the main reasons for the lack of a clear-cut approach to leadership, including the lack of a single, universal theory of leadership, the breakdown of leadership issues into components and the researchers' analysis of only selected components, omitting the others, which does not allow to show the complexity of leadership issues thoroughly, the complexity that practitioners notice daily; the lack of coherent theories of leadership stretching throughout the entire concept and the change of perceptions about leadership over the years, which is conditioned by social changes; specific approaches to leadership arose at a specific time and culture, which results in different views on effective and ineffective leadership.

The above settings can also be supplemented by the fact that leadership is not "tangible", it is a social idea of the role of a leader created in a specific social and cultural context. Saban (2007) emphasizes that "There is no ideal leadership that works in every place and at every time. Successful leaders are supported by cooperation, initiatives, and commitment to the company from their supporters."

The lack of uniformity in the approach to leadership is due to the different perceptions of a leader's effectiveness and, therefore, the behaviors that a leader should exhibit from the perspective of employees - representatives of different generations. It is indisputable that influential leaders create positive organizational cultures, strengthen motivation, and produce high-performing outcomes (Ingraham and Getha-Taylor, 2004). However, the question of behaviors through which a leader will influence employees effectively remains debatable. In this regard, it is worth contextualizing leadership in interaction.

Proponents of the study of leadership in interaction include Clifton, Larsson, and Schnurr (2020). They highlight two main advantages of this type of approach, relating leadership to interpersonal processes allows for first-hand analysis, which makes it possible to show how leadership is developed through interaction. The authors highlight the possibility of studying leadership through the following approaches: equating leadership with position, job title and focusing on the behaviors of a typical leader (Holmes, 2007; Schnurr, 2009; Yeung, 2004), viewing leadership in terms of interpersonal influence and examining the sequence of interactions occurring when influence is exerted (Clifton, 2009; Larsson and Lundholm, 2013), analyzing leadership in terms of the consequences of the influence exercised by the leader on the actions (behaviors) of subordinates (Larsson and Lundholm, 2013), and focusing on the construction of leader and subordinate identities and interactions analyzed in terms of transient phenomena, unrelated to the position but to the relationships built (Clifton, 2017; Larsson and Nielsen, 2017). 
A leader's behavior in an organization should result in improved individual as well as organizational performance. This becomes possible when leaders have the so-called psychological capital, and this psychological capital is also developed in their subordinates with an awareness of generational diversity and the differences in the needs and expectations of employees.

Issues of resilience and engagement at work (including satisfaction and happiness) about servant leadership are addressed by Youssef and Luthans (2007) and Eliot (2020), among others. They emphasize the importance of psychological capital (PsyCap) considered as confidence (self-efficacy) translating into making and putting in the necessary effort to succeed at challenging tasks; optimism about current and future effectiveness; persistence in pursuing goals; and resilience when adversity and problems arise (Luthans, Youssef, and Avolio, 2007; Luthans et al., 2007). A leader's understanding of these areas and having psychological capital determine a leader's effectiveness. The focus of servant leadership on meeting the needs of their followers, particularly the psychological needs, along with the studies linking servant leadership and increased PsyCap and humble leadership with increased follower resilience, indicate servant leadership can positively impact follower resilience (Eliot, 2020).

An approach to leadership analysis becomes even more critical given the generational diversity of the workforce, as diverse employee values and attitudes directly determine the effectiveness of a leader's actions and the social perception of those actions reflected in the leader's authority and position. Leadership skills genuinely do matter in improving the performance of public sector organizations, and the optimum style is likely an integrated one: Public sector leaders should behave mainly as transformational leaders, moderately leveraging transactional relationships with their followers and heavily leveraging the importance of preserving integrity and ethics in the fulfilment of tasks (Orazi et al., 2013).

\section{The Challenge of the Leader - Building Engagement Across Generational Diversity}

A leader in both a public, business (private sector), and social organization is a person who plays a significant role, especially in difficult times of a pandemic, shortage, excess workforce, and permanent changes in the scope of expectations, attitudes, and needs. Several challenges which a leader must undertake in order for the organization to function efficiently, not to register losses, to take an important place as an employer in the labor market, as well as not to lose its good image, places the leader in a difficult situation, requiring not only vast experience, knowledge of market mechanisms, social trends, demographic trends, but above all charisma and emotional intelligence, which increase the effectiveness of actions taken, including actions in the field of building proper interpersonal relations, organization of teamwork, as well as individual work. 
The challenges faced by a leader are additionally shaped by intergenerational differences, which significantly impact the assessment of the effectiveness of actions taken. The need to manage generational diversity, including knowledge of the specifics of a given generation, is a critical competency in building an organizational culture (including the work environment) that supports the delivery of actions, shapes appropriate behaviors, and builds a sense of community and belonging.

One of the significant leadership challenges is to build the right level of employee engagement in the activities undertaken. Involvement can be defined as a set of positive attitudes and behaviors enabling high job performance of a kind that is in tune with the organization's mission (Storey et al., 2009). Numerous studies indicate that there will be positive in-role and extra-role performance (Lee Whittington and Galpin, 2010). Since there is a link between employee well-being and the recognition and management of emotionally healthy workplaces (Zineldin and Hytter, 2012). Employee engagement also translates into higher productivity, increased job security, and job satisfaction (Buckingham and Coffman, 1999). However, to build a competitive workforce, successful organizations must establish human resource management practices that support their desired strategy and core values (Lee, Whittington, and Galpin, 2010).

To explain in detail the difficulty of building commitment, it is worth recalling the views of Quinn (1984), who emphasizes that leadership functions involve trade-offs between the simultaneous and conflicting needs of both internal and external environments. The conflicting perceptions of demanding and dominant leaders reflect two leadership tensions: control versus flexibility and reinforcement versus direction (Denison et al., 1995; Putnam et al., 2016; Zhang et al., 2015). The effect of this approach is that formal leaders focus on enforcing necessary discipline and developing desired performance standards (Denison et al., 1995), which may not correspond with the needs and expectations of all employees. By putting too much pressure and stress on subordinates, many formal leaders are viewed negatively.

An essential aspect of this respect is the employee's stage of development because employees in the early stages of development who have relatively little competence or experience usually need clear direction to maintain high-performance levels (Hersey and Blanchard, 1977). Dominant leaders (and such leaders are expected in the uniformed services, among others) may stifle employees' initiative and creativity by being inflexible in their behavior, which is why it is so essential to understand their expectations and needs and therefore to recognize the generational diversity of generations, cultural diversity is also essential (Jiang et al., 2019). This is also confirmed by Schyns and Schilling, who, in their research, indicated that employees might have different perceptions of leaders' effectiveness in terms of objective organizational performance compared to their subjective job satisfaction (Schyns and Schilling, 2011). 
The cited approaches and research confirm generational differences and, therefore, the diversity of needs and expectations. Different thought patterns corresponding to the phase of the life cycle influence the approach to work, including fulfilling work obligations and professed values (Lub et al., 2016), and are therefore also reflected in the level of engagement (Mansoor and Hassan, 2016). In particular, generational differences can be seen in interpersonal relations, teamwork, and work organization. Wishing to explore the validity of assumptions in this area and bearing in mind the views of Linley et al. (2013) according to which many perceived generational differences - including in values and attitudes towards work or colleagues - may be the result of stereotypical thinking or the influence of different contexts (Ryan and Deci, 2000; Eschleman et al., 2016), the study examined the military as a workplace for employees coming from different generations.

\section{Research Report}

The results presented in this paper are part of the research material obtained in the scientific and research work titled Shaping the commitment of soldiers in the Armed Forces - an organizational perspective. The study in the form of a questionnaire was conducted at the turn of 2019/2020, among soldiers who are students and participants of courses within the educational activities of the War Studies University. The survey aimed to determine the level of involvement of soldiers through the acceptance of statements assigned to indicators describing areas of influence on satisfaction with service in the army. For the article, indicators were selected that are influenced by the commander in the army in the perspective of strengthening the soldier's commitment, such as relations with the superior and in the team, organization of work, and training. The main research problem took the form of the question: What are the differences, if any, in the needs of generation $\mathrm{X}, \mathrm{Y}$, and $\mathrm{Z}$ employees that influence the building of employee engagement and present a challenge for the leader in a public organization?

To examine the difference between generations $\mathrm{X}, \mathrm{Y}$, and $\mathrm{Z}$ in terms of the survey questions analysed as components of the evaluation indicators, a Kruskal Wallis Htest analysis was applied. Analyses were conducted within questions for those indicators for which significant intergenerational differences were noted in the primary analysis. For questions for which significant intergenerational differences were reported, an additional post hoc analysis was performed using Dunn's test with Bonferroni significance level correction.

Table 1 presents the sociodemographic characteristics of the study sample. Most of the surveyed soldiers were male (85.4\%), born between 1970 and 1974, and held command positions (58.2\%). The length of seniority in the army was about 17 years, with the shortest seniority being less than a year and the most extended 40 years. Most respondents came from the officer corps, and the place of service was a military unit. More than $60 \%$ of the respondents belonged to the Land Forces. 
Table 1. Sociodemographic characteristics of the sample

\begin{tabular}{|c|c|}
\hline & Statistics \\
\hline \multicolumn{2}{|l|}{ Gender, $n(\%)$} \\
\hline $\mathrm{F}$ & $23(14.6)$ \\
\hline M & $135(85.4)$ \\
\hline \multicolumn{2}{|l|}{ Age, $n(\%)$} \\
\hline Before 1965 & $1(0.6)$ \\
\hline 1965-1969 & $10(6.3)$ \\
\hline $1970-1974$ & $32(20.3)$ \\
\hline 1975-1979 & $29(18.4)$ \\
\hline $1980-1984$ & $31(19.6)$ \\
\hline 1985-1989 & $24(15.2)$ \\
\hline 1990-1994 & $23(14.6)$ \\
\hline After 1995 & $7(4.4)$ \\
\hline Length of military service, $M(S D)$ & $16.91(9.49)$ \\
\hline \multicolumn{2}{|l|}{ Command functions, $n(\%)$} \\
\hline No & $64(40.5)$ \\
\hline Yes & $92(58.2)$ \\
\hline \multicolumn{2}{|l|}{ Personnel corps, $n$ (\%) } \\
\hline Officer & $122(77.2)$ \\
\hline $\mathrm{NCO}$ & $29(18.4)$ \\
\hline Professional private & $6(3.8)$ \\
\hline \multicolumn{2}{|l|}{ Place of service, $n(\%)$} \\
\hline Military unit & $115(72.8)$ \\
\hline $\begin{array}{l}\text { Institution of the Ministry of National } \\
\text { defence, General Staff, Polish Army, General } \\
\text { Headquarters, Inspectorate }\end{array}$ & $35(22.2)$ \\
\hline Military university & $2(1.3)$ \\
\hline Other & $4(2.5)$ \\
\hline \multicolumn{2}{|l|}{$\begin{array}{l}\text { Place in the organisational structure of the } \\
\text { army, } n(\%)\end{array}$} \\
\hline Land forces & $95(60.1)$ \\
\hline Air force & $20(12.7)$ \\
\hline Navy & $7(4.4)$ \\
\hline Support inspectorate & $15(9.5)$ \\
\hline Special forces & $3(1.9)$ \\
\hline Territorial Defence Forces & $8(5.1)$ \\
\hline Other & $8(5.1)$ \\
\hline
\end{tabular}

Note: Annotation $n$ - number; \% - percentage; $M$ - mean; $S D$ - standard deviation Source: Own study.

Detailed analysis of the results concerning the evaluation of the relationship with the superior showed that persons from generation $\mathrm{Z}$ were significantly less likely to agree with the statement: My supervisor takes my opinion into account compared to people from generation $\mathrm{Y}(\mathrm{p}=0.005)$ and $\mathrm{X}(\mathrm{p}=0.003)$. They also agreed significantly less with the statement: My commitment at work is noticed and appreciated by my superiors compared to people from generation $\mathrm{Y}(\mathrm{p}=0.002)$ and generation $\mathrm{X}(\mathrm{p}=$ 0.004). 
The analysis of the evaluation of team relationships showed that people from Generation $\mathrm{Z}$ also agreed less with the following statement: Employment in the military develops communication skills with other people compared to people from generation $Y(p=0.013)$ and generation $X(p=0.017)$. People from Generation $Z$ were more likely to agree with the statement: Soldiers who have connections are unpunished and can do more than people from generation $\mathrm{Y}(\mathrm{p}=0.044)$ and generation $X(p=0.026)$.

When it came to assessing the organization of work, people from generation $\mathrm{X}$ were more likely than people from generation $\mathrm{Y}$ to agree with the statement: Tasks handed over by the supervisor, the unit commander is clear, precise, and assigned with proper advance $(\mathrm{p}=0.045)$. People from generation $\mathrm{X}$ were more likely than people from generation $\mathrm{Z}$ to agree with the statement. There is a strong emphasis on cooperation between units in the military $(\mathrm{p}=0.047)$. For the other questions, the differences proved to be insignificant.

Considering, in turn, the evaluation of training, a detailed analysis of the results showed that people from generation X significantly more agreed with the statement: The military cares about the professional development of soldiers compared to people from generations $\mathrm{Y}(\mathrm{p}=0.001)$ and $\mathrm{Z}(\mathrm{p}=0.012)$. They also agreed significantly more with the statement: The army trains me sufficiently to perform my duties well compared to persons from generation $Y(p=0.002)$ and $Z(p=0.009)$. Analogous differences occurred in the case of the following statement: The military uses modern tools and techniques for training - people from generation $\mathrm{X}$ agreed with this statement more than people from generation $\mathrm{Z}(\mathrm{p}=0.002)$ and $\mathrm{Y}(\mathrm{p}=0.003)$.

People from generation $X$ were significantly more likely than people from generation $\mathrm{Z}$ to agree with the statements: In the army, access to training is clearly defined ( $\mathrm{p}=$ $0.007)$; in my daily work, I use the skills acquired during training ( $=0.013)$. People from generation $\mathrm{X}$ were significantly more likely than generation $\mathrm{Y}$ to agree with the statements: In the army, access to training is fair $(p=0.027)$. People from generation $\mathrm{Z}$ significantly less agreed with the statement: I have a say in what training I attend compared to people from generation $Y(p=0.050)$ and $X(p=0.014)$. The results of the analyses are presented in Table 2.

Table 2. Comparison of generations $X, Y$ and $Z$ in terms of analysis of individual survey questions

\begin{tabular}{|c|c|c|c|c|c|c|c|c|c|}
\hline & \multicolumn{2}{|l|}{$\mathbf{X}$} & \multicolumn{2}{|l|}{$\mathbf{Y}$} & \multicolumn{2}{|l|}{$\mathbf{Z}$} & \multirow[b]{2}{*}{$H(2)$} & \multirow[b]{2}{*}{$p$} & \multirow[b]{2}{*}{$\eta^{2}$} \\
\hline & Me & IQR & Me & IQR & Me & IQR & & & \\
\hline \multicolumn{10}{|c|}{ Evaluation of the relationship with the superior } \\
\hline $\begin{array}{l}\text { My superior is a competent } \\
\text { commander/chief }\end{array}$ & 4.00 & 2.00 & 4.00 & 1.00 & 3.00 & 1.00 & 2.21 & 0.332 & $<0.01$ \\
\hline $\begin{array}{l}\text { My supervisor treats } \\
\text { subordinates with respect }\end{array}$ & 4.00 & 0.75 & 4.00 & 1.00 & 4.00 & 0.00 & 3.34 & 0.188 & 0.01 \\
\hline $\begin{array}{l}\text { My supervisor } \\
\text { subordinates fairly }\end{array}$ & 4.00 & 1.00 & 4.00 & 1.00 & 2.00 & 2.00 & 4.61 & 0.100 & 0.02 \\
\hline $\begin{array}{l}\text { My superior provides me with } \\
\text { sufficient information }\end{array}$ & 4.00 & 1.75 & 4.00 & 2.00 & 3.00 & 1.00 & 3.46 & 0.177 & 0.01 \\
\hline
\end{tabular}




\begin{tabular}{|c|c|c|c|c|c|c|c|c|c|}
\hline & \multicolumn{2}{|l|}{$\mathbf{X}$} & \multicolumn{2}{|l|}{$\mathbf{Y}$} & \multicolumn{2}{|l|}{$\mathbf{Z}$} & \multirow[b]{2}{*}{$H(2)$} & \multirow[b]{2}{*}{$p$} & \multirow[b]{2}{*}{$\eta^{2}$} \\
\hline & Me & $I Q R$ & Me & IQR & Me & IQR & & & \\
\hline $\begin{array}{l}\text { My supervisor takes my } \\
\text { opinion into account }\end{array}$ & 4.00 & 1.00 & 4.00 & 1.00 & 2.00 & 1.00 & 10.77 & 0.005 & 0.06 \\
\hline $\begin{array}{l}\text { My involvement in my work } \\
\text { is noticed and appreciated by } \\
\text { my superiors }\end{array}$ & 4.00 & 1.00 & 4.00 & 1.00 & 2.00 & 1.00 & 11.96 & 0.003 & 0.06 \\
\hline \multicolumn{10}{|l|}{ Assessment of team relations } \\
\hline $\begin{array}{l}\text { There are few conflicts in my } \\
\text { team }\end{array}$ & 4.00 & 1.00 & 4.00 & 0.00 & 3.00 & 1.00 & 4.94 & 0.085 & 0.02 \\
\hline $\begin{array}{l}\text { The soldiers in my team } \\
\text { cooperate well with each } \\
\text { other }\end{array}$ & 4.00 & 0.00 & 4.00 & 0.00 & 4.00 & 0.00 & 4.92 & 0.086 & 0.02 \\
\hline $\begin{array}{l}\text { Employment in the military } \\
\text { develops teamwork and } \\
\text { communication skills }\end{array}$ & 4.00 & 0.00 & 4.00 & 0.00 & 3.00 & 1.00 & 8.30 & 0.016 & 0.04 \\
\hline $\begin{array}{l}\text { Teams/sections created in the } \\
\text { army have a lot of } \\
\text { independence }\end{array}$ & 3.00 & 2.00 & 3.00 & 2.00 & 2.00 & 2.00 & 1.42 & 0.491 & $<0.01$ \\
\hline $\begin{array}{l}\text { The division of labour } \\
\text { between members of a } \\
\text { team/section in the army is } \\
\text { clear }\end{array}$ & 4.00 & 1.75 & 3.00 & 2.00 & 2.00 & 1.00 & 5.94 & 0.051 & 0.03 \\
\hline $\begin{array}{l}\text { Division of labour among } \\
\text { members of the team/section } \\
\text { in the army is fair }\end{array}$ & 3.00 & 2.00 & 3.00 & 1.00 & 2.00 & 1.00 & 4.60 & 0.100 & 0.02 \\
\hline $\begin{array}{l}\text { Soldiers/employees } \\
\text { notoriously failing in their } \\
\text { duties are justly punished }\end{array}$ & 3.00 & 2.00 & 3.00 & 2.00 & 3.00 & 1.00 & 0.70 & 0.705 & 0.01 \\
\hline $\begin{array}{l}\text { Soldiers who have } \\
\text { connections are unpunished } \\
\text { and can do more }\end{array}$ & 3.00 & 1.00 & 4.00 & 1.00 & 4.00 & 1.00 & 6.91 & 0.032 & 0.03 \\
\hline \multicolumn{10}{|c|}{ Evaluation of the work organisation } \\
\hline $\begin{array}{l}\text { The work in my team is well } \\
\text { organised }\end{array}$ & 4.00 & 0.75 & 4.00 & 1.00 & 4.00 & 0.00 & 2.15 & 0.341 & $<0.01$ \\
\hline $\begin{array}{l}\text { The number of tasks I receive, } \\
\text { and the time provided for } \\
\text { their performance allow me to } \\
\text { complete them reliably and } \\
\text { within my duty hours }\end{array}$ & 2.00 & 2.00 & 2.00 & 1.00 & 2.00 & 0.00 & 5.86 & 0.053 & 0.03 \\
\hline $\begin{array}{l}\text { The tasks coming from my } \\
\text { superior, the unit commander, } \\
\text { are clear, precise and are } \\
\text { assigned well in advance }\end{array}$ & 3.00 & 2.00 & 2.00 & 1.00 & 2.00 & 1.00 & 8.46 & 0.015 & 0.04 \\
\hline $\begin{array}{l}\text { Great emphasis is put in the } \\
\text { army on cooperation between } \\
\text { units }\end{array}$ & 3.00 & 1.00 & 3.00 & 2.00 & 2.00 & 1.00 & 6.01 & 0.049 & 0.03 \\
\hline $\begin{array}{l}\text { I have sufficient knowledge } \\
\text { of the current activities of } \\
\text { other military units }\end{array}$ & 3.00 & 1.75 & 3.00 & 2.00 & 3.00 & 1.00 & 1.94 & 0.379 & $<0.01$ \\
\hline $\begin{array}{l}\text { The flow of information } \\
\text { between central and field } \\
\text { units is effective }\end{array}$ & 3.00 & 2.00 & 3.00 & 2.00 & 2.00 & 1.00 & 2.81 & 0.246 & 0.01 \\
\hline $\begin{array}{l}\text { Cooperation between central } \\
\text { and field units is appropriate }\end{array}$ & 3.00 & 2.00 & 3.00 & 1.25 & 3.00 & 0.00 & 2.52 & 0.283 & $<0.01$ \\
\hline \multicolumn{10}{|l|}{ Training evaluation } \\
\hline $\begin{array}{l}\text { The army takes care of the } \\
\text { professional development of } \\
\text { soldiers }\end{array}$ & 17.94 & $<0.001$ & 0.10 & 17.94 & $<0.001$ & 0.10 & 17.94 & $<0.001$ & 0.10 \\
\hline $\begin{array}{l}\text { In the army, access to training } \\
\text { is clearly defined. }\end{array}$ & 11.67 & 0.003 & 0.06 & 11.67 & 0.003 & 0.06 & 11.67 & 0.003 & 0.06 \\
\hline
\end{tabular}


Intergenerational Differences as a Challenge of Leaders in the Process of Building

Commitment of Employees in a Public Organization - An Empirical Research

\begin{tabular}{|c|c|c|c|c|c|c|c|c|c|}
\hline & \multicolumn{2}{|l|}{$\mathbf{X}$} & \multicolumn{2}{|l|}{$\mathbf{Y}$} & \multicolumn{2}{|l|}{$\mathbf{Z}$} & \multirow[b]{2}{*}{$H(2)$} & \multirow[b]{2}{*}{$p$} & \multirow[b]{2}{*}{$\eta^{2}$} \\
\hline & Me & $I Q R$ & Me & $I Q R$ & $M e$ & $I Q R$ & & & \\
\hline $\begin{array}{l}\text { In the army, access to training } \\
\text { is fair }\end{array}$ & 9.31 & 0.009 & 0.05 & 9.31 & 0.009 & 0.05 & 9.31 & 0.009 & 0.05 \\
\hline $\begin{array}{l}\text { I have influence on what } \\
\text { training I participate in }\end{array}$ & 8.25 & 0.016 & 0.04 & 8.25 & 0.016 & 0.04 & 8.25 & 0.016 & 0.04 \\
\hline $\begin{array}{l}\text { The army trains me } \\
\text { sufficiently so that I can } \\
\text { perform my duties well }\end{array}$ & 17.05 & $<0.001$ & 0.10 & 17.05 & $<0.001$ & 0.10 & 17.05 & $<0.001$ & 0.10 \\
\hline $\begin{array}{l}\text { The army uses modern tools } \\
\text { and methods in trainings }\end{array}$ & 18.40 & $<0.001$ & 0.11 & 18.40 & $<0.001$ & 0.11 & 18.40 & $<0.001$ & 0.11 \\
\hline $\begin{array}{l}\text { The trainings I participate in } \\
\text { are of high quality }\end{array}$ & 1.56 & 0.459 & 0.00 & 1.56 & 0.459 & 0.00 & 1.56 & 0.459 & $<0.01$ \\
\hline $\begin{array}{l}\text { I use the skills acquired } \\
\text { during the training in my } \\
\text { everyday work }\end{array}$ & 8.35 & 0.015 & 0.04 & 8.35 & 0.015 & 0.04 & 8.35 & 0.015 & 0.04 \\
\hline
\end{tabular}

Source: Own study.

In conclusion, no statistically significant differences were confirmed about all analysed dimensions of work during the conducted research, but only selected aspects. This strengthens the conviction of the validity of this type of research, which allows to confirmation assumptions by referring to objective, statistically significant relationships.

\section{Conclusions}

Multigenerational management is a challenge to be faced not only by multinational corporations but also by public organizations, which, in many countries, function as critical employers with extremely high retention rates. This generates several advantages and, above all, multitudes of challenges in terms of building the engagement of diverse generations of employees with different needs and values. Each leader in a public organization faces a whole spectrum of challenges daily, and the effects of his/her work are determined by his/her knowledge of employees, their needs, as well as the specifics of generational differences.

The research sought to answer the research question: What are the differences, if any, in the needs of generation $\mathrm{X}, \mathrm{Y}$, and $\mathrm{Z}$ employees that influence the building of employee engagement and present a challenge for the leader in a public organization? The research conducted among soldiers confirmed that cultural difference, resulting from the diversity of generations, presents a challenge for commanders in the military. From the perspective of a direct relationship with a formal leader such as a commander, it is a challenge to meet the needs of representatives of generation $\mathrm{Z}$. A demanding, dominating, and enforcing discipline commander may negatively influence the engagement of a young soldier, who expects to be noticed and appreciated for his/her contribution to the service and to have his/her opinion taken into consideration. Expectations towards the army characteristic for generation $\mathrm{Z}$ can also be seen in opinions concerning relations in the team, organization of work, and training. Threats that may reduce the involvement of young soldiers include: 
- the sanctioning of relationships based on acquaintances as a basis for satisfying service:

- a deficit in the development of communication skills in team relationships,

- a training system to which access is not clearly defined and which does not use modern training tools and techniques. This aspect also shows a greater need for the young soldier to influence the choice of the training in which he/she wants to participate.

The study also confirmed the different thought patterns characterizing the representatives of generation $\mathrm{X}$ in interpersonal relations, teamwork, and work organization. This age group is characterized by acceptance of the current way of giving orders by superiors, the way of appreciating engagement in service, and communication in task teams. Soldiers of generation $\mathrm{X}$ accept the current standards of training of soldiers, not paying attention to the need for changes in the way of selecting people for training and techniques of conducting them. The bridge between generations seems to be generation $\mathrm{Y}$, which on the one hand, understands the standards of team management on the part of the commander and the specifics of relations between soldiers, resulting from the nature of a hierarchical organization. On the other hand, generation $\mathrm{Y}$ sees the need for changes in the way tasks are delegated, and soldiers are educated.

Summarising the above, the challenge for the army is to prepare commanders so that the tradition, principles, and values of this organization are continued; on the other hand, changes in the team and organizational operations are essential. Building the commitment of employees who are different in terms of generation is not an easy task. Therefore, military leaders should be prepared for this task, which will allow them to understand the needs of employees more fully and thus to shape the organizational culture in which the fundamental values will continue to be cultivated.

\section{References:}

Avery, G.C. 2009. Przywództwo w organizacji. Paradygmaty i studia przypadków. Polskie Wydawnictwo Ekonomiczne, Warsaw.

Benson, J., Brown, M. 2011. Generations at work: are there differences and do they matter? The International Journal of Human Resource Management, 22(9), 1843-1865.

Bolton, R.N., Parasuraman, A., Hoefnagels, A., Migchels, N., Kabadayi, S., Gruber, T., Komarova. Y., Solnet, L.D. 2013. Understanding Generation Y and Their Use of Social Media: A Review and Research Agenda. Journal of Service Management, 24(3), 245-267. DOI 10.1108/09564231311326987.

Buckingham, M., Coffman, C. 1999. First, break all the Rules: What the World's Greatest Managers do Differently. Simon \& Shuster, New York, NY.

Clifton, J. 2009. Beyond taxonomies of influence: 'doing' influence and making decisions in management team meetings. Journal of Business Communication, 46(1), 57-79.

Clifton, J. 2017. Taking the (heroic) leader out of leadership. The in-situ practice of distributed leadership in decision-making talk. In: Ilie, C., Schnurr, S. (Eds.) 
Challenging Leadership Stereotypes through Discourse. Singapore: Springer, 4568.

Clifton, J., Larsson, M., Schnurr, S. 2020. Leadership in interaction. An introduction to the Special Issue. Leadership, 1-11. DOI: 10.1177/1742715020954790.

Costanza, D.P., Darrow, J.B., Yost, A.B., Severt, J.B. 2017. A Review of Analytical Methods Used to Study Generational Differences: Strengths and Limitations. Work, Aging and Retirement, 3(2), 149-165. DOI: 10.1093/workar/wax002.

Denison, D.R., Hooijberg, R., Quinn, R.E. 1995. Paradox and performance: Toward a theory of behavioral complexity in managerial leadership. Organization Science, 6, 524540.

Eliot, J.L. 2020. Resilient Leadership: The Impact of a Servant Leader on the Resilience of their Followers. Advances in Developing Human Resources, 22(4), 404-418. DOI: $10.1177 / 1523422320945237$.

Eschleman, K.J., King, M., Mast, D., Ornellas, R., Hunter, D. 2016. The Effects of Stereotype Activation on Generational Differences. Work, Aging and Retirement, 3(2)200-208. DOI: 10.1093/workar/waw032.

Eyerman, R., Turner, B. 1998. Outline of a Theory of Generations. European Journal of Social Theory, 1, 91-106.

Goštautaitè, B., Bučiūnienè, I., Milašauskienè, Ž. 2019. HRM and work outcomes: the role of basic need satisfaction and age. The International Journal of Human Resource Management, 1-34. DOI: 10.1080/09585192.2019.1683049.

Hersey, P., Blanchard, K.H. 1977. Management of Organizational Behavior: Utilizing Human Resources, 3rd ed. New Jersey: Prentice Hall.

Holmes, J. 2007. Humour and the construction of Maori leadership at work. Leadership, $3(1), 5-27$.

Ingraham, P.W., Getha-Taylor, H. 2004. Leadership in the Public Sector. Review of Public Personnel Administration, 24(2), 95-112. DOI: 10.1177/0734371X04263323.

Jiang, X., Xu, S., Houghton, J.D., Manz, C.C. 2019. Shades of grey in implicit effective leadership: Searching for clarity in the midst of paradox. Leadership, 15(6), 673695. DOI: 10.1177/1742715019827405.

Larsson, M., Lundholm, S.E. 2013. Talking work in a bank: A study of organizing properties of leadership in work interactions. Human Relations, 66(8), 11011129.

Larsson, M., Nielsen, M.F. 2017. The risky path to a followership identity: from abstract concept to situated reality. International Journal of Business Communication, 58(1), 3-30. DOI: $10.1177 / 2329488417735648$.

Lee Whittington, J., Galpin, T.J. 2010. The engagement factor: building a high-commitment organization in a low-commitment world. Journal of Business Strategy, 31(5), 14-24. DOI: $10.1108 / 02756661011076282$.

Lub, X.D., Bal, P.M., Blomme, R.J., Schalk, R. 2016. One job, one deal...or not: do generations respond differently to psychological contract fulfilment? The International Journal of Human Resource Management, 27(6), 653-680. DOI: 10.1080/09585192.2015.1035304.

Luthans, F., Avolio, B.J., Avey, J.B., Norman, S.M. 2007. Positive psychological capital: Measurement and relationship with performance and satisfaction. Personnel Psychology, 60(3), 541-572.

Lyons, S.T., Schweitzer, L., Eddy, S.W. 2015. How have careers changed? An investigation of changing career patterns across four generations. Journal of Managerial Psychology, 30(1), 8-21. 
Mannheim, K. 1952. The Problem of Generations. In P. Kecskemeti (Ed.), Essays on the Sociology of Knowledge. London: Routledge and Kegan Paul, 276-320.

Mansoor, F., Hassan, Z. 2016. Factors influencing Employee Engagement: A study on a Telecommunication Network provider in Maldives. International Journal of Accounting and Business Management, 4(1), 50-64. DOI: 10.24924/ijabm/2016.04/v4.iss1/50.64.

Mazur-Wierzbicka, E. 2015. Kompetencje pokolenia Y - wybrane aspekty. Studia i prace Wydziału Nauk Ekonomicznych i Zarządzania, 39(3), Wydawnictwo Naukowe Uniwersytetu Szczecińskiego.

McMullin, J., Comeau, T., Jovic, W. 2007. Generational Affinities and Discourses of Difference: A Case Study of Highly Skilled Information Technology Workers. British Journal of Sociology, 58(2), 297-316.

Orazi, D.C., Turrini, A., Valotti, G. 2013. Public sector leadership: new perspectives for research and practice. International Review of Administrative Sciences, 79(3), 486-504. DOI: 10.1177/0020852313489945.

Putnam, L.L., Fairhurst, G.T., Banghart, S. 2016. Contradictions, dialectics, and paradoxes in organizations: A constitutive approach. Academy of Management Annals, 10(1), 65-171.

Quinn, R.E. 1984. Applying the competing values approaches to leadership: Toward an integrative model. In: Hunt, J.G., Stewart, R., Schriesheim, C., et al. (eds) Managers and Leaders: An International Perspective. New York: Pergamon, 10.

Ryan, R.M., Deci, E.L. 2000. Self-determination theory and the facilitation of intrinsic motivation, social development, and well-being. American Psychologist, 55(1), 68-78. DOI: 10.1037/0003-066X.55.1.68.

Schnurr, S. 2009. Constructing leader identities through teasing at work. Journal of Pragmatics, 41(6), 1125-1138.

Schuman, H., Scott, J. 1989. Generations and Collective Memories. American Sociological Review, 54(3), 359-381.

Schyns, B., Schilling, J. 2011. Implicit leadership theories: Think leader, think effective? Journal of Management Inquiry, 20, 141-150.

Smola, K., Sutton, C. 2002. Generational Differences: Revisiting Generational Work Values for the New Millennium. Journal of Organizational Behaviour, 23(4), 363-382.

Stanimir, A. 2015. Generation Y - Characteristics of Attitudes on Labour Market. Mediterranean Journal of Social Sciences, 6(2), 22-28. DOI: 0.5901/mjss.2015.v6n2s5p22.

Statistical Yearbook of the Republic of Poland 2020 Year. Retrieved from: www.stat.gov.pl.

Storey, J., Welbourne, T., Wright, P., Ulrich, D. (Eds.) 2009. The Routledge Companion to Strategic Human Resource Management: Employee engagement.

Szaban, J.M. 2007. Zachowania organizacyjne. Aspekt międzykulturowy. Wyd. Adam Marszałek, Torun.

Trzesniewski, K.H., Donnellan, M.B. 2010. Rethinking “Generation Me": A study of cohort effects from 1976-2006. Perspectives on Psychological Science, 5(1), 58-75. DOI:10.1177/1745691609356789.

Twenge, J.M., Campbell, S.M., Hoffman, B.J., Lance, C.E. 2010. Generational differences in work values: Leisure and extrinsic values increasing, social and intrinsic values decreasing. Journal of Management, 36, 1117-1142. DOI: $10.1177 / 0149206309352246$.

Yeung, L. 2004. The paradox of control in participative decision-making: gatekeeping discourse in banks. International Journal of the Sociology of Language, 166, 83104. 
Youssef, C.M., Luthans, F. 2007. Positive organizational behavior in the workplace: The impact of hope, optimism, and resilience. Journal of Management, 33(5), 774800.

Zhang, Y., Waldman, D.A., Han, Y., Li, X. 2015. Paradoxical leader behaviours in people management: antecedents and consequences. Academy of Management Journal, 58, 538-566.

Zineldin, M., Hytter, A. 2012. Leaders' negative emotions and leadership styles influencing subordinates' well-being. The International Journal of Human Resource Management, 23(4), 748-758. DOI: 10.1080/09585192.2011.606114. 